\title{
Chilling-tolerant U.S.-processing Cucumber (Cucumis sativus L.): Three Advanced Backcross and Ten Inbred Backcross Lines
}

\author{
Jack E. Staub ${ }^{1}$ \\ Vegetable Crops Research, U.S. Department of Agriculture, Agricultural \\ Research Service, Department of Horticulture, University of Wisconsin, \\ Madison, WI 53706; and U.S. Department of Agriculture, Agricultural \\ Research Service Forage and Range Research Laboratory, 696 N. 1100 E., \\ Logan, UT 84322
}

\section{Vanessa S. Gordon}

Vegetable Crops Research, U.S. Department of Agriculture, Agricultural Research Service, Department of Horticulture, University of Wisconsin, Madison, WI 53706; and U.S. Department of Agriculture, Agricultural Research Service U.S. Sugarcane Field Station, 12990 US Highway 441 N., Canal Point, FL 33438

\section{Philipp Simon}

Vegetable Crops Research, U.S. Department of Agriculture, Agricultural Research Service, Department of Horticulture, University of Wisconsin, Madison, WI 53706

\section{Todd C. Wehner \\ Department of Horticultural Science, North Carolina State University, Raleigh, NC 27695-7609}

Additional index words. plastid inheritance, vegetable breeding, cucumber germplasm

Environmental stresses such as chilling temperatures can reduce seed germination rate, seedling emergence rate, flower and fruit development, marketable yield, and postharvest fruit storage longevity in cucumber (Cucumis sativus L.) (Staub and Bacher, 1997; Staub and Wehner, 1996). Chilling temperatures occur in unpredictable patterns, making it difficult to implement management practices for crop protection. Moreover, response of cucumber seedlings to chilling depends on pre- and postchilling environment. Therefore, breeding for tolerance to chilling is an attractive management tool to minimize crop loss.

Chilling injury at the first true-leaf stage in cucumber is controlled by simple plastidic

Received for publication 9 Apr. 2015. Accepted for publication 21 May 2015

The cost of publishing this paper was defrayed in part by the payment of page charges. Under postal regulations, this paper therefore must be hereby marked advertisement solely to indicate this fact. Mention of a trade name, proprietary product, or specific equipment does not constitute a guarantee or warranty by the USDA and does not imply its approval to the exclusion of other products that may be suitable.

${ }^{1}$ Corresponding author. E-mail: jack.staub@ars. usda.gov. (maternal; Chung et al., 2003) and nuclear (parental; Kozik and Wehner, 2008) factors. While Chung et al. (2007) identified three putative plastidic single-nucleotide polymorphisms (SNPs) associated with chilling tolerance in processing cucumber 'Chipper', Kozik and Wehner (2008) characterized one dominant nuclear gene, $C h$, in line NC-76 (derived from PI 246930). The response of chilling tolerant 'Chipper' and line NC-76 seedlings challenged at $4{ }^{\circ} \mathrm{C}$ for $5.5 \mathrm{~h}$ under $270 \mu \mathrm{mol} \cdot \mathrm{m}^{-2} \cdot \mathrm{s}^{-1}$ photosynthetic photon flux irradiance are similar (Gordon and Staub, 2011).

No chilling-tolerant U.S.-processing cucumber varieties are commercially available. Although the processing cultivar Chipper (released in 1968 from Clemson University, Clemson, SC) possesses plastid genes for chilling tolerance in the seedling stage, its yield and quality are substantially lower than current cultivars. Therefore, experiments were undertaken to introgress the plastid chilling tolerance of 'Chipper' (donor parent) into the commercially acceptable processing cucumber line M29 [recurrent parent; experimental inbred line $\left(\mathrm{S}_{11}\right)$, North Carolina State University, Raleigh, NC] via backcrossing and self-pollination (Gordon and Staub, 2013). As a result, a series of three advanced backcross $\left(\mathrm{ABL} ; \mathrm{BC}_{5}\right)$ and 10 inbred backcross (IBL; $\mathrm{BC}_{2} \mathrm{~S}_{3-5}$ ) chilling-tolerant U.S. processing lines possessing acceptable yield and quality traits are being released by the Agricultural Research Service (ARS), U.S. Department of Agriculture (USDA). The chilling tolerance of backcross progeny is characterized by their response to chilling stress $\left(5.5 \mathrm{~h}\right.$ at $4{ }^{\circ} \mathrm{C}$ in $270 \mu \mathrm{mol} \cdot \mathrm{s}^{-2} \cdot \mathrm{m}^{-2} \mathrm{cool}$ white lighting) at the first true-leaf stage under controlled environmental conditions. These lines provide chilling-tolerant genetic stocks suitable for immediate use by cucumber improvement programs.

\section{Origin}

Breeding lines were developed through initial reciprocal matings made between chilling tolerant 'Chipper' (CH is used hereafter to indicate tolerant cytoplasmic constitution) and chilling sensitive processing line M29 (M designates sensitive constitution) to produce $F_{1}$ progeny for backcrossing to the recurrent parent, line M29 (Gordon and Staub, 2013). NCSU M 29 was developed from the cross of two accessions, PI 222783 ('Khiar Sabz') × PI 222985 ('Khiar'). These PIs were crossed in 1980 and their progeny selected for cold germination ability in 19821986 in controlled-germination chambers, and finished as an $\mathrm{S}_{11}$ inbred. Chillingsensitive and tolerant advanced backcross (ABL; $\mathrm{BC}_{1}-\mathrm{BC}_{5}$ ) and inbred backcross (IBL; $\mathrm{BC}_{2} \mathrm{~S}_{1-5}$ ) lines were created from $\mathrm{F}_{1}$ reciprocal chilling-sensitive and tolerant lines by backcrossing to a cloned recurrent parent of the alternate chilling response type [i.e., tolerant ('Chipper') and sensitive (M29), respectively] parental line. Exact reciprocal $\mathrm{F}_{1}$ progeny for comparative genotypic and phenotypic analyses were developed by crossing 'Chipper' and M29 to produce germplasm in chilling-tolerant $(\mathrm{CH}$; 'Chipper' $\times$ M29) and in sensitive $(\mathrm{M}$; M29 × 'Chipper') maternal plastidic backgrounds.

Reciprocal $\mathrm{F}_{1} \mathrm{~S}$ intended to produce chilling-tolerant $\mathrm{ABL}$ were backcrossed to their paternal genetic donor five times to produce $\mathrm{BC}_{1}-\mathrm{BC}_{5}$ progeny. For production of IBL, 240 randomly chosen reciprocal ABL $\mathrm{BC}_{2}$ progeny (i.e., 120 chilling-sensitive $\mathrm{ABL} \quad \mathrm{BC}_{2}$, and 120 chilling-tolerant $\mathrm{ABL}$ $\mathrm{BC}_{2}$ ) were self-pollinated five times to produce the sensitive and tolerant [containing the M29 plastid (MIBL), and tolerant 'Chipper' plastid (CHIBL), respectively] $\mathrm{BC}_{2} \mathrm{~S}_{5}$ progeny. Attrition due to seedling death and lack of seed set during reciprocal backcrossing yielded a set $\left(\mathrm{BC}_{1}-\mathrm{BC}_{5}\right)$ of $10 \mathrm{ABL}$ (i.e., five each-chilling tolerant and sensitive) and 163 (i.e., 57 CHIBL and 106 MIBL) IBL for molecular genotyping, chilling tolerance testing, and field evaluation.

\section{Line Evaluation}

Initially, progeny within the $\mathrm{F}_{1}$ and $\mathrm{BC}_{1}$ $\mathrm{BC}_{5}$ generations of the two $\mathrm{ABL}$ chilling response types were phenotyped for chilling response in the University of Wisconsin Biotron-controlled environmental facility 






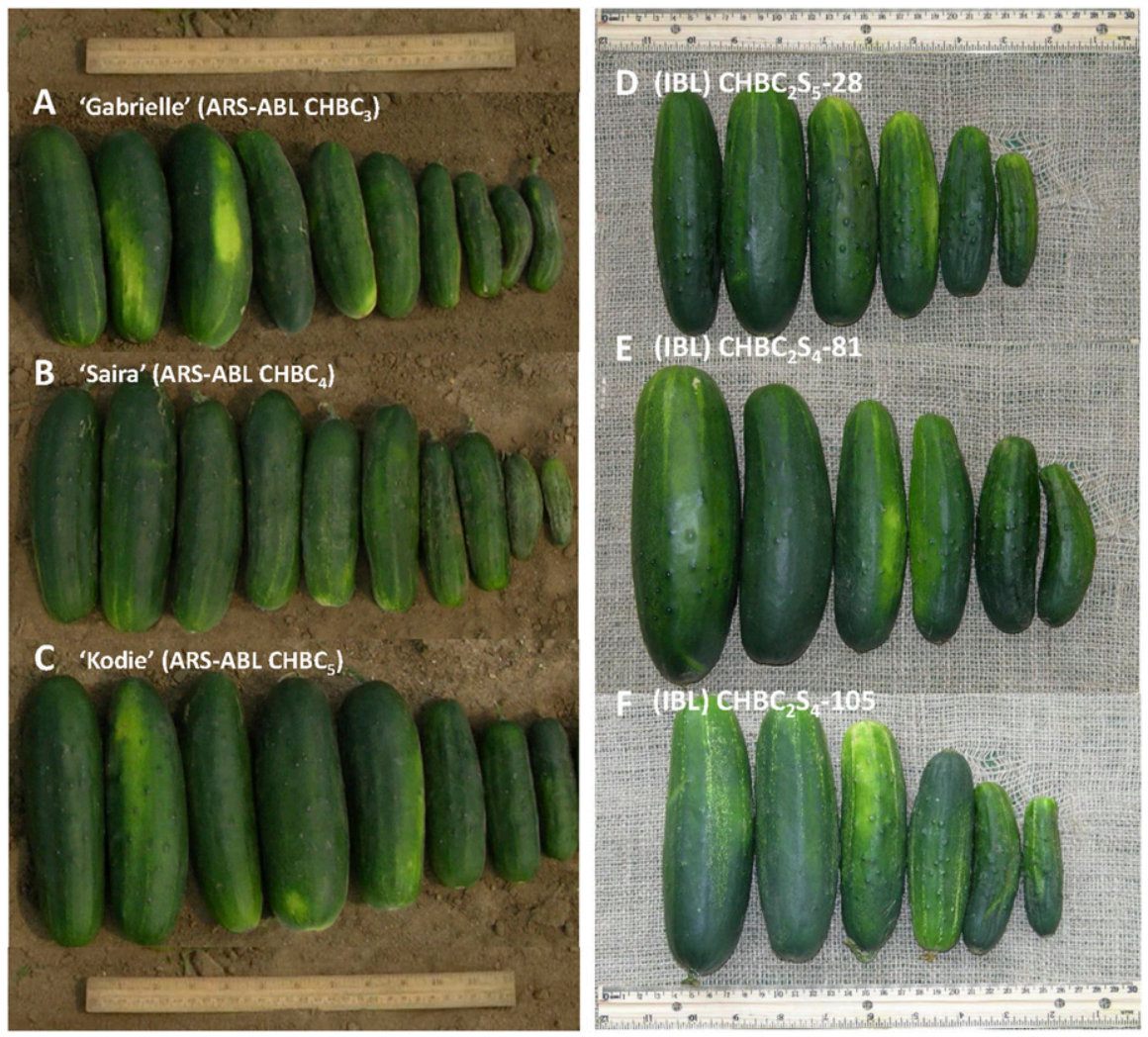

Fig. 1. Fruits of chilling tolerant $\left(4^{\circ} \mathrm{C}\right)$ cucumber (Cucumis sativus $\mathrm{L}$.) advanced backcross lines (ABL) 'Gabrielle' (Panel A; ARS-ABL CHBC 3 ), 'Saira' (Panel B; ARS-ABL CHBC 4 ), and 'Kodie' (Panel C; ARS-ABL $\mathrm{CHBC}_{5}$ ), and tolerant inbred backcross lines (IBL) $\mathrm{CHBC}_{2} \mathrm{~S}_{4}-28$ (Panel D), $\mathrm{CHBC}_{2} \mathrm{~S}_{4}-81$ (Panel E), and $\mathrm{CHBC}_{2} \mathrm{~S}_{4}-105$ (Panel F). Plastid chilling tolerance derived from 'Chipper' $(\mathrm{CH})$ as the donor parent.

(Madison, WI) to confirm their predicted chilling response based on their cytoplasmic constitutions (Gordon, 2009; Gordon and Staub, 2011; Gordon and Staub, 2013). Subsequently, both chilling-tolerant and chillingsensitive $\mathrm{ABL}$ [i.e., $\mathrm{BC}_{1}-\mathrm{BC}_{5}$ generations (5) in each of 2 lineages] and CHIBL (i.e., 10 of $57 \mathrm{BC}_{2} \mathrm{~S}_{4-5}$ generated from $1 \mathrm{BC}_{2}$ ) were genotyped using 11 simple sequence repeat (SSR) codominant markers, and then evaluated in field plots for their general horticultural performance (i.e., yield and quality) and general combining ability (GCA) for four economically important traits. Genetic relationships among ABL, CHIBL, and parents were determined on the basis of Principal Component Analysis (PCA). Predictably, PCA results indicated that ABL were genotypically similar to line M29 and IBL were genetically diverse, but more similar to M29 than to 'Chipper'.

To estimate GCA estimation, ABL and CHIBL were crossed with elite processing cultigens (i.e., lines H-19, 7012, WI 1983G, 5551, Gy 14, and 'Addis') (Gordon and Staub, 2013). Parents, progeny (BC, and $F_{1}$ ), and control cultivar Vlasset were evaluated for days to anthesis, sex expression type, fruit length $(\mathrm{L})$ :diameter $(\mathrm{D})$ ratio $(\mathrm{L}: \mathrm{D})$, and yield in replicated trials at each of four harvests in 2006 and five harvests in 2007, at the University of Wisconsin Experiment Station at Hancock, WI. In addition, 44 CHIBL were also evaluated for these traits to determine their horticultural acceptability. Some ABL (10) and IBL (12) differed from their nonrecurrent and both parents, respectively, in many of the traits measured. The phenotypic variation among IBL was remarkably broad (Table 1 ).

\section{Description}

On the basis of genotypic and phenotypic analysis, large portions of the nuclear genome of the recurrent parent (and its phenotype) were recovered by the $\mathrm{BC}_{2}$ generation, with nearly complete recovery of recurrent ring by the $\mathrm{BC}_{3}$ in $\mathrm{ABL}$ (Gordon and Staub, 2013). The GCA of IBL was significant $(P<$ 0.001 ) for yield, fruit size, fruit length, fruit and genotypic and phenotypic characteristics when compared with their parents and the control cultivars, three chilling-tolerant $\mathrm{ABL}$ (designated 'Gabrielle' ARS CHBC 3 , 'Saira' $\mathrm{ARS} \mathrm{CHBC}_{4}$, and 'Kodie' ARS $\mathrm{CHBC}_{5}$ ), and 10 chilling-tolerant IBL (designated ARS $\mathrm{CHBC}_{2} \mathrm{~S}_{4}-10,-14,-17,-34,-64,-81,-96$, $-101,-105$, and $\mathrm{CHBC}_{2} \mathrm{~S}_{5}-28$ ) are being released for commercial use (Table 1). The ABL and IBL are intended for the development of elite chilling-tolerant cultivars (Fig. 1). The quality (e.g., size) and yield characteristics of chilling-tolerant $\mathrm{ABL}$ Gabrielle, Saira, and Kodie and some IBL (e.g., $\mathrm{CHBC}_{2} \mathrm{~S}_{4}-14$ and -17) are similar to or parental traits and its nuclear genome occurdiameter, and L:D ratio. Given their GCA better than the control cultivar Vlasset under Wisconsin growing conditions.

Though not tested directly for chilling tolerance, all IBLs were molecularly genotyped against the set of three previously described plastidic tolerance-associated SNPs (Chung et al., 2007; Gordon and Staub, 2013). Their phenotypic response to chilling (resistant or sensitive) is predictable based upon previous chilling studies conducted on the original parents and other chillingtolerant germplasm. With the presence of the tolerant plastid and SNP-based genotype assessment, as well as the known nuclear response to chilling of the recurrent parent (susceptible; M29), the ABLs and IBLs resulting from the initial 'Chipper' $\times$ M29 cross are chilling tolerant (i.e., no visible necrotic symptoms) at the first true-leaf stage under the chilling conditions under which the parents were evaluated (i.e., $5.5 \mathrm{~h}$ at $4{ }^{\circ} \mathrm{C}$ ).

\section{Availability}

Seed of chilling tolerant ABL and IBL from a hand-pollinated greenhouse increase may be obtained by addressing requests to P.W. Simon, Vegetable Crops Research, U.S. Department of Agriculture, Agricultural Research Service, Department of Horticulture, University of Wisconsin, Madison, WI 53706.

\section{Literature Cited}

Chung, S.M., J.E. Staub, and G. Fazio. 2003. Inheritance of chilling injury: A maternally inherited trait in cucumber. J. Amer. Soc. Hort. Sci. 128:526-530.

Chung, S.M., V.S. Gordon, and J.E. Staub. 2007. Sequencing of cucumber (Cucumis sativus L.) chloroplast genomes identifies differences between chilling tolerant and susceptible cucumber lines. Genome 50:215-225.

Gordon, V.S. 2009. Characterizing plastome variation and its contribution to chilling injury tolerance in cucumber (Cucumis sativus L.). PhD Diss. University of Wisconsin, Madison (OCoLC: Ocn648006186). 20 July 2015. <http:// search.proquest.com/docview/305029867? accountid $=14761>$.

Gordon, V.S. and J.E. Staub. 2011. Comparative analysis of chilling response in cucumber through plastidic and nuclear genetic effects component analysis. J. Amer. Soc. Hort. Sci. 136:256-264.

Gordon, V.S. and J.E. Staub. 2013. Backcross introgression of plastomic factors controlling chilling tolerance into elite cucumber (Cucumis sativus L.) germplasm: Early generation recovery of recurrent parent phenotype. Euphytica 195:217-234.

Kozik, E.U. and T.C. Wehner. 2008. A single dominant gene $c h$ for chilling resistance in cucumber seedlings. J. Amer. Soc. Hort. Sci. 133:225-227.

Staub, J.E. and T.C. Wehner. 1996. Noninfectious disorders: Temperature stress, p. 66. In: T.A. Zitter, D.L. Hopkins, and C.E. Thomas (eds.). Compendium of cucurbit diseases Part II. APS Press, St. Paul, MN

Staub, J.E. and J. Bacher. 1997. Cucumber as a processed vegetable. In: D.S. Smith, J.N. Cash, W.-K. Nip, Y.H. Hui (eds.). Processing vegetables: Science and technology IV. Technomic Publishing Co., Inc. Lancaster, PA. 